\title{
ETHANOL-INDUCED CELL AGGREGATION (FLOCCULATION) AND ITS PHYSIOLOGICAL BACKGROUND IN SCHIZOSACCHAROMYCES POMBE RIVE 4-2-1*
}

\author{
AnNa MarÁz** and AnNa Geleta \\ Department of Microbiology and Biotechnology, Faculty of Food Science, Szent István University, \\ H-1118 Budapest, Somlói út 14-16, Hungary
}

(Received: August 31, 2000; accepted: October 5, 2000)

\begin{abstract}
Cell aggregation (flocculation) of the yeast Schizosaccharomyces pombe strain RIVE 4-2-1 developed in glucose-containing medium, but only in the presence of ethanol. Cell surface proteins which participated in cell to cell interactions were characterised by the susceptibility of flocculation to different proteolytic enzymes, heat treatment, denaturing and thiol compounds and by the inhibition of flocculation by sugars and derivatives. It was shown that a galactose-specific lectin was involved in this new type of flocculation.
\end{abstract}

Keywords: Schizosaccharomyces pombe - flocculation - ethanol - lectin

\section{INTRODUCTION}

Flocculation, the typical non-sexual aggregation of cells, is a relatively widespread phenomenon among different yeast species. Much more is known about the flocculation of brewer's yeasts and of laboratory strains of Saccharomyces cerevisiae (for a review see [12]). The flocculation of cells generally develops during the late exponential or early stationary growth phase, but also occurs exceptionally at the beginning of the exponential phase, as in case of Kluyveromyces bulgaricus [4].

Flocculation is under genetic control [18], but cultural and nutritional conditions also play an important role in the expression of the flocculation phenotype [10]. The involvement of lectin or lectin-type proteins and carbohydrate receptors of the cell wall in flocculation was first demonstrated in Saccharomyces cerevisiae [7] and later in Kluyveromyces bulgaricus [4], Schizosaccharomyces pombe [5], Saccharomycodes ludwigii [14] and in Zygosaccharomyces strains [15]. Bivalent cations, preferably $\mathrm{Ca}^{2+}$, are a prerequisite for flocculation, their role being the reversible activation of lectins by ensuring the proper conformation $[9,16]$. Flocculation is reversibly lost by chelating $\mathrm{Ca}^{2+}$ with EDTA or by adding specific sugars, which compete with cell wall receptors for lectin binding $[4,8]$, or by mild heat treatment [17].

\footnotetext{
*Dedicated to Professor Lajos Ferenczy on the occasion of his 70th birthday.

**Corresponding author; e-mail: amaraz@omega.kee.hu
} 
The flocculation constituents, especially lectins, can be well defined by the structures of simple sugars, which specifically inhibit flocculation. In some strains of Saccharomyces cerevisiae, mannose-specific lectins govern flocculation by interacting with the outer-chain mannan side-branches of the cell wall [13]. In a flocculent strain of Kluyveromyces bulgaricus, galactose- and N-acetyl glucosamine-specific lectins were isolated [1], while in Zygosaccharomyces fermentati a mannose-specific lectin was also involved in flocculation [15].

Lectin-mediated flocculation in Schiz. pombe L972 and L975 strains developed only when the cells were cultured under carbon- or nitrogen-limitation. Deflocculation occurred on addition of $50 \%$ galactose or $10 \mathrm{mM}$ EDTA and the flocs were metastable in water [5].

The aims of this study were to determine the physiological conditions which influence the expression of the flocculent phenotype of Schiz. pombe strain RIVE 4-2-1 and to characterise the cell surface components playing roles in the cell to cell interaction.

\section{MATERIALS AND METHODS}

\section{Organism and media}

Schiz. pombe RIVE strain 4-2-1 was obtained from the Culture Collection of Yeasts, Bratislava, Slovakia. Shaken cultures were propagated in YEPD broth $(0.5 \%$ yeast extract, $0.5 \%$ peptone, $1 \%$ glucose), at $180 \mathrm{rpm}$ at $25^{\circ} \mathrm{C}$ for 24 hours.

\section{Preparation of deflocculated cell suspension}

Shaken cultures were prepared in YEPD broth supplemented with $6 \%(\mathrm{v} / \mathrm{v})$ ethanol. $50 \mathrm{mM}$ EDTA- $\mathrm{Na}_{2}(\mathrm{pH} 8)$ was added and the homogeneous cell suspension was centrifuged $(2500 \times g, 10 \mathrm{~min})$. Sedimented cells were washed twice with deionized water and the absorbance of the suspension $\left(\mathrm{A}_{400 \mathrm{~nm}}\right)$ was adjusted to 1.5 .

\section{Determination of flocculation index}

EDTA-deflocculated cells were suspended in deionized water at a concentration of $\mathrm{A}_{400 \mathrm{~nm}}$ 1.5. Two $\mathrm{ml}$ aliquots were distributed into test tubes and a series of twices dilutions was made with solutions of different salts, as indicated in Table 1. After mixing, the suspensions were allowed to sediment for 5 minutes and the absorbance $\left(\mathrm{A}_{400 \mathrm{~nm}}\right)$ was measured with Novaspec II spectrophotometer (Pharmacia). As a control, a deflocculated cell suspension of the same volume was applied and measured in the same way as the sample. The flocculation index (FI) was calculated according to the equation $\mathrm{FI}=1-\left(\mathrm{A}_{\text {sample }} / \mathrm{A}_{\text {control }}\right)$. The FI values theoretically vary between 0 
and 1. Our strain had FI values of $0.5-0.6$ in case of the best flocculation, while a value of 0.1 or less was taken as virtually complete deflocculation.

\section{Flocculation at different $p H$ values}

Buffers described by Stratford were used [11]. At pH's below $2.0 \mathrm{HCl}$ was used at pH's above 9.0, $\mathrm{NaOH}$ was applied.

\section{Measurement of calcium content of cell suspensions}

Cells were sedimented by centrifugation and the $\mathrm{Ca}^{2+}$-content of the supernatant was determined with an atomic absorption spectrophotometer of type 902 (GBC Ltd.).

\section{Enzyme treatment of flocculent cells}

Flocculent cells were treated with cell wall lytic enzymes, proteases and carbohydrases according to Hodgson et al. [2]. The following enzymes were used: Trichoderma lysing enzyme $200 \mu \mathrm{g} \mathrm{ml}^{-1}$, Basidiomycetes driselase $200 \mu \mathrm{g} \mathrm{ml}^{-1}$, Arthrobacter lyticase $10 \mu \mathrm{g} \mathrm{ml}^{-1}, \beta$-glucuronidase $200 \mu \mathrm{g} \mathrm{ml}^{-1}$, proteinase $\mathrm{K} 200 \mu \mathrm{g} \mathrm{ml}^{-1}$, pronase E $200 \mu \mathrm{g} \mathrm{ml}^{-1}$, trypsin $100 \mu \mathrm{g} \mathrm{ml}^{-1}, \alpha$-chymotrypsin $100 \mu \mathrm{g} \mathrm{ml}^{-1}, \beta$-glucosidase $200 \mu \mathrm{g} \mathrm{ml}^{-1}$ and $\alpha$ - or $\beta$-galactosidase $200 \mu \mathrm{g} \mathrm{ml}^{-1}$. All enzymes were purchased from Sigma.

The flocculation grade was determined visually after treatment for $15,30,75$ or 120 minutes at $37^{\circ} \mathrm{C}$.

\section{Sugar and lectin inhibition tests}

To determine the sugar specificity of flocculation, different sugars and derivatives were added together with $50 \mathrm{mM} \mathrm{CaCl} 2$ to the homogeneous cell suspension in the following concentrations: $1200 \mathrm{mM}, 750 \mathrm{mM}, 500 \mathrm{mM}, 250 \mathrm{mM}, 100 \mathrm{mM}, 50 \mathrm{mM}$, $10 \mathrm{mM}$ and $5 \mathrm{mM}$. The mannose-specific lectin concanavalin $\mathrm{A}$ and the galactosespecific lectin abrin (both from Sigma) were added to the $\mathrm{Ca}^{2+}$-reflocculated cell suspensions $\left(\mathrm{A}_{400}=0.5\right)$ at concentrations of $4,2,1,0.5$ and $0.25 \mathrm{mg} \mathrm{ml}^{-1}$.

\section{RESULTS}

\section{Effects of culturing conditions on expression of flocculation phenotype}

Floc formation of Schiz. pombe strain RIVE 4-2-1 in YEPD medium was observed in static cultures, under a low oxygen content (fermentative conditions) when the cells entered the stationary phase of growth. The cells remained dispersed, however, 
when the cultures were aerated by shaking and the cells produced no ethanol. The direct role of ethanol and not the mode of glucose catabolism (i.e. by respiration or by fermentation) in the induction of flocculation was evident, because shaken (respiring) cultures flocculated readily and strongly when more than $4 \%(\mathrm{v} / \mathrm{v})$ of ethanol was added to the culture medium. The optimal concentration of ethanol was between $6 \%$ and $8 \%$ (data not shown). The effect of ethanol was limited to the very early stage of growth, because strong flocculation developed only when ethanol was present at the time of inoculation. The flocculability decreased if ethanol was supplemented after the cells started multiplying, but was without effect when the cells entered the exponential phase of growth (data not shown). Flocculation started, however, only in the late exponential growth phase and was completed by the beginning of the stationary phase, independently of whether it was induced at the start or later. The addition of ethanol to a stationary culture was completely ineffective even during a longer (e.g. one day) incubation period.

The hydrogen ion concentration of the culture medium was indifferent as concerns flocculation, because the cells were able to propagate and flocculate equally well in YEPD - ethanol broth at the $\mathrm{pH}$ range between 3.0 and 7.0.

\section{Roles of monovalent and bivalent cations in flocculation}

Sedimented flocs of cells remained fairly aggregated after several washings with deionized water, but immediate deflocculation took place on the addition of EDTA$\mathrm{Na}_{2}$ in the concentration range of $10-50 \mathrm{mM}$. Flocculation was restored by suspend-

Table 1

Flocculation-inducing effects of bivalent and monovalent cations on Schizosaccharomyces pombe RIVE 4-2-1

\begin{tabular}{|c|c|c|c|c|c|}
\hline \multirow{2}{*}{ Salt } & \multicolumn{5}{|c|}{ Concentration } \\
\hline & $0.01 \mathrm{M}$ & $0.05 \mathrm{M}$ & $0.10 \mathrm{M}$ & $0.15 \mathrm{M}$ & $0.20 \mathrm{M}$ \\
\hline $\mathrm{CaCl}_{2}$ & $0.51 \pm 0.06^{\mathrm{a}}$ & $0.53 \pm 0.07$ & $0.42 \pm 0.12$ & $0.45 \pm 0.13$ & $0.37 \pm 0.12$ \\
\hline $\mathrm{MgCl}_{2}$ & $0.50 \pm 0.14$ & $0.51 \pm 0.06$ & $0.52 \pm 0.04$ & $0.56 \pm 0.11$ & $0.49 \pm 0.07$ \\
\hline $\mathrm{CoCl}_{2}$ & $0.42 \pm 0.14$ & $0.44 \pm 0.03$ & $0.38 \pm 0.07$ & $0.33 \pm 0.06$ & $0.35 \pm 0.12$ \\
\hline $\mathrm{CuSO}_{4}$ & $0.21 \pm 0.11$ & $0.03 \pm 0.03$ & $0.02 \pm 0.01$ & $0.09 \pm 0.04$ & $0.11 \pm 0.03$ \\
\hline $\mathrm{MnCl}_{2}$ & $0.28 \pm 0.03$ & $0.05 \pm 0.01$ & $0.07 \pm 0.01$ & $0.08 \pm 0.06$ & $0.12 \pm 0.01$ \\
\hline $\mathrm{ZnCl}_{2}$ & $0.54 \pm 0.12$ & $0.55 \pm 0.05$ & $0.45 \pm 0.06$ & $0.35 \pm 0.10$ & $0.30 \pm 0.12$ \\
\hline $\mathrm{KCl}$ & $0.49 \pm 0.06$ & $0.50 \pm 0.10$ & $0.49 \pm 0.08$ & $0.42 \pm 0.05$ & $0.40 \pm 0.06$ \\
\hline $\mathrm{NaCl}$ & $0.45 \pm 0.03$ & $0.41 \pm 0.06$ & $0.39 \pm 0.08$ & $0.50 \pm 0.05$ & $0.45 \pm 0.05$ \\
\hline
\end{tabular}

a The degree of flocculation was determined as the flocculation index (FI), as defined in the Materials and methods.

Values are means of the results of three independent experiments ( \pm S.D.). 
ing the cells in salt solutions containing bivalent $\left(\mathrm{Ca}^{2+}, \mathrm{Mg}^{2+}, \mathrm{Zn}^{2+}\right.$ or $\left.\mathrm{Co}^{2+}\right)$ and monovalent $\left(\mathrm{K}^{+}\right.$or $\left.\mathrm{Na}^{+}\right)$cations, but $\mathrm{Mn}^{2+}$ and $\mathrm{Cu}^{2+}$ proved to be ineffective (Table 1). This reinduced flocculation was reversed again on the addition of EDTA-Na $\mathrm{N}_{2}$, even in those cases when reflocculation was achieved with $\mathrm{K}^{+}$and $\mathrm{Na}^{+}$. This suggested that these monovalent cations probably did not have a direct role in flocculation. Their effect could have been caused by the triggering of a set of events which finally led to the excretion of bivalent cations (probably $\mathrm{Ca}^{2+}$ ) which activated flocculation, similarly, as occurred in Saccharomyces cerevisiae [11]. To prove this, the concentration of $\mathrm{Ca}^{2+}$ excreted by the cells in the presence of $\mathrm{KCl}$ or $\mathrm{NaCl}$ was determined. The amount of $\mathrm{Ca}^{2+}$ released into the medium after 15 minutes of treatment was 0.11 and $0.17 \mathrm{mM}$ in cases of $100 \mathrm{mM} \mathrm{KCl}$ and $\mathrm{NaCl}$, respectively. The $\mathrm{Ca}^{2+}$ concentration of the suspending medium was further increased when cell wall bound $\mathrm{Ca}^{2+}$ was released by the addition of $50 \mathrm{mM}$ EDTA- $\mathrm{Na}_{2}$. The values were 0.17 and $0.21 \mathrm{mM} \mathrm{Ca}^{2+}$ in $\mathrm{KCl}$ and $\mathrm{NaCl}$ solutions, respectively.

\section{Effects of $\mathrm{pH}$ on floc formation}

The effects of $\mathrm{pH}$ values between 1 and 12 on deflocculation and the inhibition of reflocculation were monitored. The flocs remained intact and dispersed cells reflocculated readily on the addition of $\mathrm{Ca}^{2+}$ in the very wide $\mathrm{pH}$ range from 2 to 12 , while only the $\mathrm{pH}$ below 2 inhibited reflocculation and caused a slow breaking-down of the flocs.

\section{Effects of enzymes, urea and sulphydryl compounds on flocculation}

Cell surface components thought to be involved in the cell to cell interactions were characterised by treating dispersed cells for a short time or by prolonged exposure to protein-denaturing agents (SDS and urea), sulphydryl compounds (2-mercaptoethanol and dithiothreitol), cell wall lytic enzyme complexes (lysing enzyme, lyticase and driselase), proteases (pronase $\mathrm{E}$, proteinase $\mathrm{K}$, trypsin and $\alpha$-chymotrypsin) and carbohydrases ( $\beta$-glucuronidase, $\beta$-glucosidase and $\alpha$ - or $\beta$-galactosidase). The floc forming ability of the cells was lost on treatment for 15 minutes in all cases except SDS, thiol compounds and carbohydrases, even after exposure for 2 hours.

\section{Heat stability of flocculation}

The effects of heat on deflocculation were studied by gradually heating $\mathrm{Ca}^{2+}$-reflocculated cells until the $T_{F}$ value was reached, at which point the flocs were completely deflocculated [17]. In case of RIVE 4-2-1, the $\mathrm{T}_{\mathrm{F}}$ value proved to be $55^{\circ} \mathrm{C}$. At this temperature, deflocculation was proved to be reversible by allowing suspensions to cool down to room temperature. On further elevation of temperature, however, floc- 
Table 2

Effect of heat treatment on flocculation of Schizosaccharomyces pombe RIVE 4-2-1

\begin{tabular}{|c|c|c|c|c|c|c|}
\hline \multirow{2}{*}{$\begin{array}{l}\text { Duration of } \\
\text { heat treatment } \\
\quad(\mathrm{min})\end{array}$} & \multirow{2}{*}{$\begin{array}{l}\text { Medium of } \\
\text { heat } \\
\text { treatment }\end{array}$} & \multicolumn{5}{|c|}{ Temperature } \\
\hline & & $60^{\circ} \mathrm{C}$ & $65^{\circ} \mathrm{C}$ & $70^{\circ} \mathrm{C}$ & $75^{\circ} \mathrm{C}$ & $80^{\circ} \mathrm{C}$ \\
\hline \multirow[t]{2}{*}{30} & $\mathrm{CaCl}_{2}$ & $0.43 \pm 0.08^{b}$ & $0.33 \pm 0.10$ & $0.10 \pm 0.05$ & $0.09 \pm 0.01$ & $0.04 \pm 0.01$ \\
\hline & D.W. & $0.36 \pm 0.09$ & $0.46 \pm 0.09$ & $0.41 \pm 0.05$ & $0.51 \pm 0.03$ & $0.08 \pm 0.02$ \\
\hline \multirow[t]{2}{*}{60} & $\mathrm{CaCl}_{2}$ & $0.55 \pm 0.06$ & $0.26 \pm 0.03$ & $0.11 \pm 0.03$ & $0.08 \pm 0.01$ & $0.01 \pm 0.01$ \\
\hline & D.W. & $0.48 \pm 0.08$ & $0.28 \pm 0.03$ & $0.37 \pm 0.06$ & $0.40 \pm 0.05$ & $0.16 \pm 0.03$ \\
\hline \multirow[t]{2}{*}{90} & $\mathrm{CaCl}_{2}$ & $0.40 \pm 0.07$ & $0.25 \pm 0.04$ & $0.08 \pm 0.02$ & $0.07 \pm 0.03$ & $0.01 \pm 0.01$ \\
\hline & D.W. & $0.37 \pm 0.06$ & $0.29 \pm 0.07$ & $0.33 \pm 0.06$ & $0.36 \pm 0.03$ & $0.03 \pm 0.01$ \\
\hline \multirow[t]{2}{*}{120} & $\mathrm{CaCl}_{2}$ & $0.42 \pm 0.08$ & $0.21 \pm 0.02$ & $0.09 \pm 0.01$ & $0.10 \pm 0.02$ & $0.02 \pm 0.02$ \\
\hline & D.W. & $0.49 \pm 0.10$ & $0.33 \pm 0.09$ & $0.36 \pm 0.08$ & $0.35 \pm 0.06$ & $0.04 \pm 0.02$ \\
\hline
\end{tabular}

${ }^{a}$ Cells were suspended in $50 \mathrm{mM} \mathrm{CaCl}{ }_{2}\left(\mathrm{CaCl}_{2}\right)$ or deionized water (D.W.) at a concentration of $\mathrm{A}_{400 \mathrm{~nm}}=0.75$.

${ }^{\mathrm{b}}$ The degree of flocculation was determined as the flocculation index (FI), as defined in the Materials and methods.

Values are means of the results of three independent experiments ( \pm S.D.)

culation ceased to be reversible at $70^{\circ} \mathrm{C}$. The floc-forming ability of the cells was tested by heat treatment in deionized water or in $50 \mathrm{mM} \mathrm{CaCl}_{2}$. The data presented in Table 2 clearly indicate that $50 \mathrm{mM} \mathrm{CaCl}{ }_{2}$ as a heat-treating medium made the cells more sensitive to the denaturing effect of heat than did deionized water. Prolongation of the treatment from 30 to 120 minutes was without effect in both cases.

\section{Flocculation inhibitory effects of sugars and derivatives}

The results of the above experiments strongly suggested that lectin-like cell surface proteins were involved in cell aggregation in the case of Schiz. pombe strain RIVE 4-2-1. The sugar specificity of lectins was determined by testing the flocculation inhibitory effects of various sugars and sugar derivatives in the presence of $\mathrm{Ca}^{2+}$ (Table 3). Although most of them caused slight or complete inhibition of the flocculation at high (1.2 M) concentration, only D-galactose, 2-deoxy-D-galactose and disaccharides bearing $\beta$-linked $\mathrm{D}$-galactose in a terminal, non-reducing position (lactose and o-nitrophenyl- $\beta$-D-galactoside) maintained this ability through a long series of dilutions, indicating the presence of galactose-specific lectin-like proteins in the cell surface. Compounds containing $\alpha$-linked $\mathrm{D}$-galactose at the terminal, non-reducing end had a reduced inhibitory effect, e.g. p-nitrophenyl- $\alpha$-D-galactoside, or they were completely ineffective, e.g. melibiose and raffinose. 
Table 3

Flocculation inhibitory effects of sugars and derivatives on Schizosaccharomyces pombe RIVE 4-2-1

\begin{tabular}{lc}
\hline \multicolumn{1}{c}{ Carbohydrate } & Concentration (mM) \\
\hline Fructose & $-\mathrm{b}$ \\
D-Mannose & - \\
D-Sorbitol & - \\
D-Mannitol & - \\
D-Glucose & $1200^{\mathrm{a}}$ \\
2-Deoxy-D-glucose & - \\
Maltose & - \\
Saccharose & - \\
D-Galactose & 100 \\
2-Deoxy-D-galactose & 250 \\
N-Acetyl-D-galactosamine & - \\
Lactose & 50 \\
o-Nitrophenyl- $\beta$-D-galactoside & 50 \\
$p$-Nitrophenyl- $\alpha$-D-galactoside & 250 \\
Melibiose & - \\
Raffinose & - \\
\end{tabular}

Cells were suspended in $50 \mathrm{mM} \mathrm{CaCl}_{2}$, at a concentration of $\mathrm{A}_{400}=0.75$.

a Values are the minimal concentrations required for complete deflocculation of the cells, based on the repetition of three independent experiments.

$\mathrm{b}_{-}$: No deflocculation even at the highest concentration (1200 $\mathrm{mM}$ ) applied.

\section{Effects of exogenous lectins on flocculation}

The flocculation inhibitory effects of the manno-specific lectin concanavalin A and of the galactose-specific lectin, abrin on the ethanol-grown cells were monitored. As expected, concanavalin A had no effect, but abrin inhibited flocculation in the concentration range of $1-4 \mathrm{mg} \mathrm{ml}^{-1}$. In the latter case, the inhibitory effect was probably a consequence of the competition of abrin with the endogenous cell-surface lectins of the cells.

\section{DISCUSSION}

A new cell aggregation (flocculation) phenotype, which developed only in the presence of ethanol, was discovered in Schiz. pombe strain RIVE 4-2-1. For definition and discrimination of the surface lectins, the susceptibility of flocculation to different proteolytic enzymes, heat treatment, denaturing and thiol compounds [2,9] proved very useful in this case, too. Further typing of the cell surface lectin by sugar 
specificity proved not only that the terminal monosaccharide and the mode of glycosidic linkage (i.e. $\alpha$ or $\beta$ ) determines the binding of carbohydrate to the lectin, but also that the attached part of the terminal monosaccharide can modify or alter the binding. While the flocculation of strain RIVE 4-2-1, governed by a galactose-specific lectin, was inhibited by both p-nitrophenyl- $\beta$-D-galactoside and o-nitrophenyl$\alpha$-D-galactoside, their disaccharide analogues, lactose and melibiose, respectively, had different deflocculating effects: lactose gave rise to inhibition, but melibiose did not. The lack of an inhibitory effect of the natural $\alpha$-galactosides melibiose and raffinose was surprising because the Schiz. pombe cell wall contains terminal, non-reducing $\alpha$-galactoside residues in its phosphogalactomannan outer cell wall layer [3].

What can the role of ethanol be in the flocculation of this strain? One possibility is that it modifies the structure of the flocculation receptor by altering the galactomannan side-branches, similarly as methanol acts in a weakly flocculent strain of Pichia pastoris [6]. It is also possible that chemical modification concerns the lectin itself by activating the molecules for binding to the carbohydrate moieties. It cannot be excluded, however, that specific metabolic pathways are induced by ethanol, which directly or indirectly lead to cell aggregation. To elucidate this, further work is needed.

\section{ACKNOWLEDGEMENTS}

The authors wish to thank Katalin Nagy for her skilful technical assistance, and Yde Steensma for a critical reading of the manuscript. This work was supported by the Hungarian Scientific Research Fund OTKA, contract No. T 4256.

\section{REFERENCES}

1. Al-Mahmood, S., Giummelly, S. P., Bonaly, R., Delmotte, F., Monsigny, M. (1988) Kluyveromyces bulgaricus yeast lectin. J. Biol. Chem. 263, 3930-3934.

2. Hodgson, J. A., Berry, D. R., Johnston, J. R. (1985) Discrimination by heat and protease treatment between flocculent phenotypes conferred on Saccharomyces cerevisiae by the genes FLOI and FLO5. J. Gen. Microbiol. 131, 3219-3227.

3. Horisberger, M., Rossett, J. (1977) Localization of $\alpha$-galactomannan on the surface of Schizosaccharomyces pombe cells by scanning electron microscopy. Arch. Microbiol. 112, 123-126.

4. Hussain, T., Salhi, O., Lematre, J., Charpentier, C., Bonaly, R. (1986) Comparative studies of flocculation and deflocculation of Saccharomyces uvarum and Kluyveromyces bulgaricus. Appl. Microbiol. Biotechnol. 23, 269-273.

5. Johnson, B. F., Walker, T., Calleja, G. B., Seligy, V. L. (1988) Sexual co-flocculation and asexual selfflocculation in budding and fission yeasts: experimental establishment of fundamental difference. Can. J. Microbiol. 34, 1105-1107.

6. Mbawala, A., Al-Mahmood, S., Loppinet, V., Bonaly, R. (1990) Acetolysis and ${ }^{1}$ H NMR studies on mannans isolated from very flocculent cells of Pichia pastoris IFP 206. J. Gen. Microbiol. 136, $1279-1284$

7. Miki, B. L. A., Poon, N. H., James, A. P., Seligy, V. L. (1982) Possible mechanism for flocculation interaction governed by gene FLO1 in Saccharomyces cerevisiae. J. Bacteriol. 150, 878-889.

8. Mill, P. J. (1964) The nature of interactions between flocculent cells in the flocculation of Saccharomyces cerevisiae. J. Gen. Microbiol. 35, 63-68. 
9. Nishihara, H., Toraya, T., Fukui, S. (1982) Flocculation of cell wall of brewer's yeast and effect of metal ions, protein denaturants and enzyme treatments. Arch. Microbiol. 131, 112-115.

10. Soares, E. V., Teixeira, J. A., Mota, M. (1994) Effect of cultural and nutritional conditions on the control of flocculation expression in Saccharomyces cerevisiae. Can. J. Microbiol. 40, 851-857.

11. Stratford, M. (1989) Yeast flocculation: Calcium specificity. Yeast 5, 487-496.

12. Stratford, M. (1992) Yeast flocculation: a new perspective. Adv. Microb. Physiol. 33, 1-71.

13. Stratford, M. (1992) Yeast flocculation: Receptor definition by mnn mutants and concanavalin A. Yeast 8, 635-645.

14. Stratford, M., Pearson, B. M. (1992) Lectin-mediated flocculation of the yeast Saccharomycodes ludwigii NCYC 734. Lett. Appl. Microbiol. 14, 214-216.

15. Suzzi, G., Romano, P., Benevelli, M. (1992) The flocculation of wine yeasts: biochemical and morphological characteristics in Zygosaccharomyces - flocculation in Zygosaccharomyces. A. van Leeuwenhoek 61, 317-322.

16. Taylor, N. W., Orton, W. L. (1973) Effect of the alkaline earth metal salts on flocculence in Saccharomyces cerevisiae. J. Inst. Brew. 79, 294-297.

17. Taylor, N. W., Orton, W. L. (1975) Calcium in flocculence of Saccharomyces cerevisiae. J. Inst. Brew. $81,53-57$.

18. Teunissen, A. W. R. H., Steensma, H. Y. (1995) Review: The dominant flocculation genes of Saccharomyces cerevisiae constitute a new subtelomeric gene family. Yeast 11, 1001-1013. 
